\title{
A Great Time to Be a Statistician
}

\author{
Ronald L. Wasserstein
}

Note: The opinions expressed here are not necessarily those of Notices.

Responses on the Notices webpage are invited.

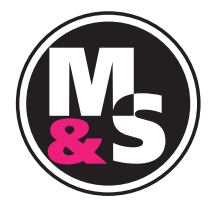

Taking my cue from David Eisenbud and Kirsten Bohl, as I write this I am sitting at my desk just a few miles south of where the cherry blossoms will be harbingers of springtime. However, looking out my window on a chilly January day, barren trees and salty streets say nothing but winter, winter, winter.

As you read this, however, it is Mathematics and Statistics Awareness Month, and it is a great time to make students aware of the opportunities afforded them through study of and careers in math and stats. Our research reveals that when today's high school and college students think about what they would like to do, they want to do work that can make a difference in the world, work that will challenge their intellect and satisfy their curiosity, work that is enjoyable, and (naturally) work that pays well. It is hard to beat mathematics and statistics for jobs that fit these aspirations.

And the word is getting out! Four of the top ten highest rated jobs in the current CareerCast.com survey are directly related to our professions. Similarly, four of the top ten best graduate degrees as ranked by Fortune magazine are in mathematics and statistics. USNews . com ranks "statistician" as number four in its list of twenty-five best jobs. This kind of recognition shows up in other rankings as well, and is being reflected in student degree choices. Since 2010, according to IPEDS data, the number of mathematics bachelors degrees awarded has

Ron Wasserstein is executive director of the American Statistical Association. His e-mail address is ron@amstat.org.

For permission to reprint this article, please contact: reprint-permission@ams .org.

DOI: http://dx.doi.org/10.1090/noti1505 grown by 28 percent, and in statistics by a whopping 170 percent. (That's starting from a smaller base, but still very encouraging.)

The mathematics community, as David and Kirsten have pointed out, is doing wonderful things to promote the importance of mathematics. At the end of this brief column, I say a quick word about one of them. The statistics community is also hard at work to increase student awareness of the value of basic statistical literacy and the potential for careers in statistics. Our biggest investment is an outreach initiative called "This Is Statistics" (www .thisisstatistics.org), and we're very encouraged with the results of this program as it enters its third year. Thousands of students are learning that statistics-the science of learning from data, and of measuring, controlling, and communicating uncertainty-is an excellent career choice.

While 2016 has been labeled the "worst year ever," an assertion that, historical considerations aside, almost any mathematician or statistician would dispute on extreme value theory grounds alone, it was a good year for statistics. ASA Director of Science Policy Steve Pierson has documented this well in his blog "Nine Recognitions for Statistics in 2016." 2

Of these nine, a highlight for me was the announcement of the first recipient of the International Prize in Statistics. The contributions of Sir David $\operatorname{Cox}^{3}$ have impacted

$1 \longdiv { \text { https://www .nytimes.com/2016/12/28/opinion/2016 } }$ -worst-year-ever.htm1?_r=1

$\sqrt[2]{\text { community.amstat.org/blogs/steve-pierson/2016/12/29 }}$ /nine-recognitions-for-statistics-in-2016

3 www . wor 1dofstatistics.org/fi1es/2016/10/W0S news1etter_10202016_SPECIAL.pdf 
the well-being of most of us, so it was fitting that Dr. Cox is the winner of the statistics equivalent of top prizes in other fields, such as the Abel Prize in mathematics. These prizes serve to remind the public that the work of statisticians and mathematicians may be very abstract but it often impacts how we live.

In this "post-truth world," mathematicians and statisticians everywhere ought to engage the public to increase understanding in and trust of our fields. It is encouraging to see how much great work in the area of public engagement is already being done by our communities.

One sterling example of public engagement is the National Museum of Mathematics, which my ASA colleague Donna LaLonde and I visited last year. We spent part of our time viewing the exhibits, and part of our time just watching visitors engage with them. In the building that day were a large group of middle school-aged children. In our observation it wasn't obvious that a single child learned anything specific about mathematics, but it was clear that they all came away with the idea that mathematics is pretty cool. That's an idea very much worth planting, and we are excited to work with you to grow awareness and enthusiasm for mathematics and statistics.

\section{Photo Credit}

Photo of Ronald L. Wasserstein and family is courtesy of Ronald L. Wasserstein.

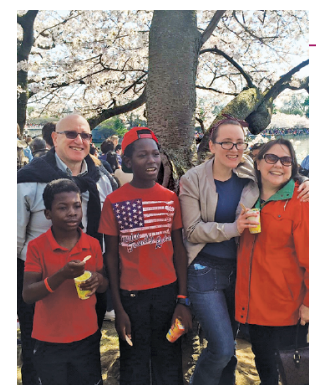

\section{ABOUT THE AUTHOR}

Ron Wasserstein and family (Peterson, Abner, Rose, and Sherry) enjoying the cherry blossoms in Washington, DC.
Ronald L. Wasserstein

\section{Let Your Voice Be Heard!}

\section{Do you enjoy what you're reading in the Notices?}

\section{Would you like to see an article on a certain topic? Person? Situation?}

Then we want to hear from you. Use our Notices Online Commentary Feature to post your general comments and suggestions:

\section{www.ams.org/notices}

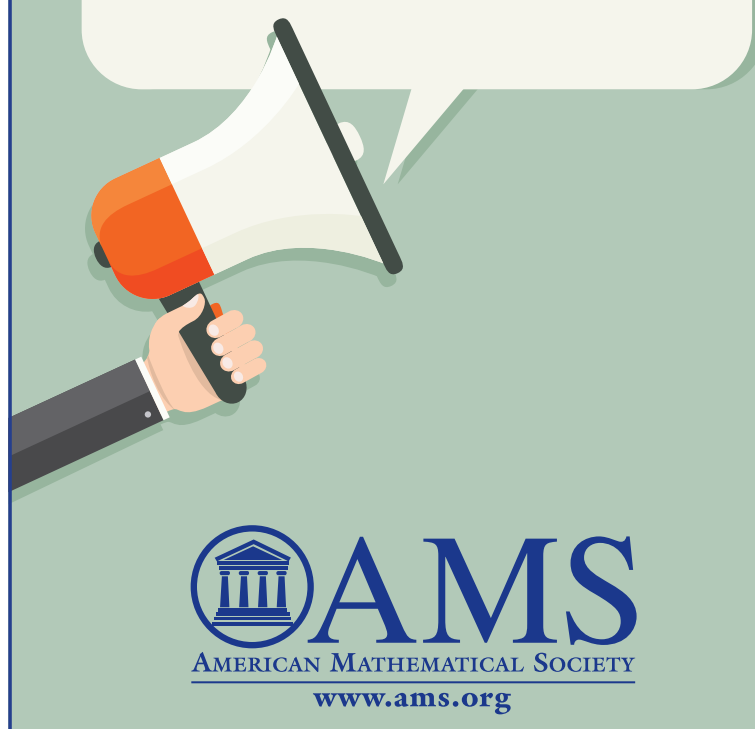

